International Journal of Health Sciences
Available online at www.sciencescholar.us
Vol. 6 No. 1, April 2022, pages: $347-356$
e-ISSN: 2550-696X, p-ISSN: 2550-6978
https://doi.org/10.53730/ijhs.v6n1.4381

\title{
Management of Medical Institutions on Context of Provision Medical and Preventive Care in COVID-19 Condition
}

\begin{abstract}
\begin{tabular}{l} 
Iryna Okhabska a, Vira Budzyn ${ }^{\text {b }}$, Ivan Rybchych c, Ivan Zyma d, Yurii Kalichak e \\
Manuscript submitted: 25 September 2021, Manuscript revised: 7 December 2021, Accepted for publication: 20 January 2022 \\
\hline
\end{tabular}

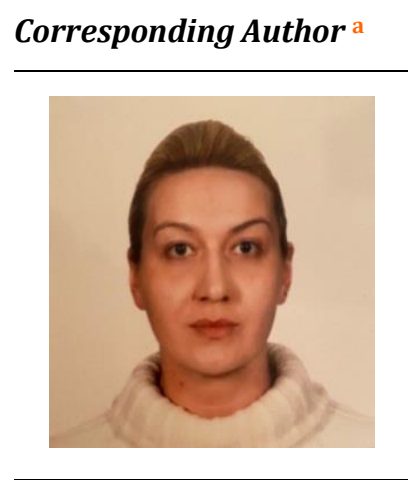

\section{Keywords}

COVID-19 pandemic; health care system; medical care; medical management; medical preventive; medical service;

Abstract

The aim of the study management of medical institutions in the context of providing medical and preventive care in conditions of COVID-19 is an urgent research problem because it provides detection of management's effective mechanism in times of crisis. It was to identify the management's peculiarities of medical institutions in the context of providing medical and preventive care in conditions of COVID-19. The article uses a qualitative content analysis method, a method of comparison, and a method of analysis of countries' cases in the context of rendering medical and preventive care in Ukraine, Spain, Italy, Germany, and the Czech Republic. The article identifies the main elements of the health system management mechanism during the pandemic, which includes coordinated work by stakeholders to ensure a coordinated response to the emergency. The mechanism includes the organizational, legal, and financial components of cooperation between agencies and ministries of national, regional level, involvement international organizations in the process of development of policy and tactics, management crisis' strategies. Strategic documents of the national level are one of the main elements of the management's system.
\end{abstract} public health;
International Journal of Health Sciences (C) 2022. This is an open access article under the CC BY-NC-ND license (https://creativecommons.org/licenses/by-nc-nd/4.0/). 


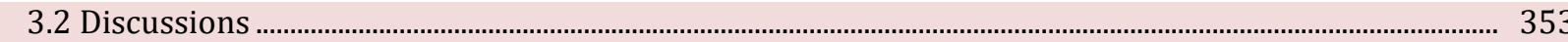

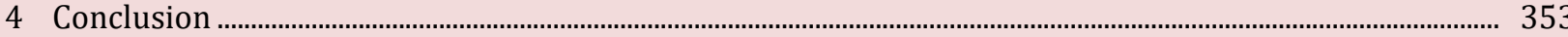

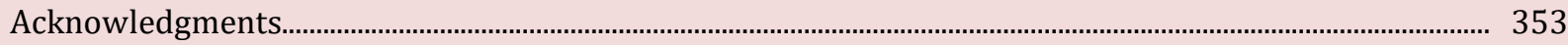

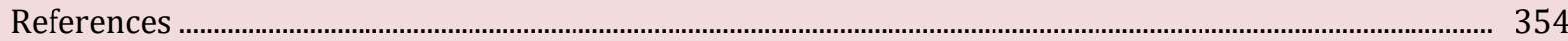

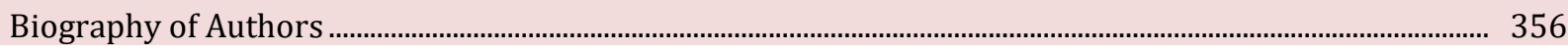

\section{Introduction}

Immediate caused a crisis health care system in different countries, especially in regions of mass disease. Management of medical institutions should be directed at solving the problem of material and technical support, providing labor, financial, information resources (Correia et al., 2015). By the way, within the EU, COVID-19 Health Systems Response Monitor (HSRM) has been established to collect and systematize information about the actions of different countries to reduce the negative consequences of the disease (COVID-19 Health System Response Monitor, 2022A). The National Institutes of Public Health (NPHIs) monitored the virus. Management of medical institutions under COVID-19 conditions is expected to implement plans of response to pandemics and management by governments to ensure continuity of their functioning (Bokhoree et al., 2014; Jang et al., 2006). Management envisages implementation of response mechanisms to emergencies, information transmission' ways, medical services' regulation to patients (Wheeler et al., 2015).

Under the conditions of the spread of COVID-19 medical institutions' management required the centralized management's use based on daily monitoring and disease control (Barzylovych et al., 2020). The development and information systems' implementation of situation control has been provided at the level of ministries in different countries to get that done. Hotlines for patients counseling have been integrated. The patient's way of medical and preventive care has been simplified. These trends require detailed study to assess the effectiveness of medical institutions' management in the context of providing medical and preventive care in conditions (Saghazadeh \& Rezaei, 2020).

\section{Literature review}

Medical institutions of health protection discussed in the literature are:

- Digitization, integration of its solutions into medical institutions, supply chains, pharmaceutical industry, eHealth development;

- COVID-19 pandemic and health challenges. These two topics are examined as closely related ones in the context of medical care and pressure reduction and medical staff and hospital infrastructure.

Scientists have noted the low level of telemedicine development to the pandemic, even in the EU, the US, and China. During the period of the virus' spread this state of digitalization forced the government and medical institutions to react quickly, implementing digital monitoring tools and innovative remote methods of personnel work through information and communication means (Fasano et al., 2020).

Digitalization is one of the effective management components in the context of providing medical care during a pandemic (Garmann-Johnsen et al., 2020). At the same time, the lack of digital strategies in medical institutions has caused management challenges of the health care system, which are connected with the need for the dynamic introduction of digital tools during the crisis, changes in the system development strategies, the need for development of a dizhitalization plan, etc. (Gjellebæk et al., 2020; Zhao \& Canales, 2021; Beaulieu \& Bentahar, 2021; Odone et al., 2019). The rapid pace of technology implementation during the pandemic has also caused many problems related to medical personnel's training, changes in communication with patients, document management, financing. Due to the lack of funding for health institutions in countries (Joint decoration of the European Commission and who/Europe (who/Europe) "Partnerships for health in the who European Region" (2010), the implementation of technologies became a challenge that has largely declined during the crisis (Shamshurina et al., 2021). 
The literature proposes the introduction of technologies, artificial intelligence, big data (Glauner et al., 2021), for the development of medical institutions and increases the efficiency of rendering of medical services (solving problems of communication, exchange of medical institutions through it-solution) (Lapão, 2019). Digital technologies are seen as a factor of value formation and medical services added value (Kokshagina, 2021), which simplify business processes and ensure the transfer of routine functions to the working technique's performance. That is why technologies significantly reduce the burden on medical personnel in conditions of medical personnel's lack, particularly during the pandemic, solving the problem of providing medical care through remote medicine (Paital et al., 2020; Roy et al., 2020). Technologies have contributed to Health development - the formation of innovative working processes, the transition of managers, patients, staff to the resolution of the problems related to diagnostics of the population's health. The development of eHealth involves the development of medical personnel's digital skills, patients in the use of technology by stakeholders (Gjellebæk et al., 2020). Digital platforms are transforming communications, medical services, experience sharing, staff knowledge, and document management (Moro Visconti \& Midea, 2020; Wahyuni et al., 2022).

\section{Materials and Methods}

The article uses a method of qualitative content analysis using COVID-19 Health System Response Monitor (2022a), Health Care System of Ukraine (2022), World Health Organization (2021), National eHealth policy or strategy exists. The comparison method is used to discuss differences in key elements of medical institution management in the context of providing medical and preventive care in Ukraine, Spain, Italy, Germany, and the Czech Republic. The country case analysis method is used to identify key differences and key benefits which have ensured effective management of medical institutions in the context of the disease's spread. The mechanism of the health care system's management is defined in the example of the Ukraine case (Economou et al., 2015).

\section{Results and Discussions}

\subsection{Results}

During the spread of the pandemic, reforms in the health care system and decentralization were taking place in Ukraine, having a positive impact on the management of health facilities (Todurov et al., 2021). However, at the time of detection, the first case of the virus spread on March 6, 2020, there was no plan on how to respond it in the country. On March 24, 2020, the Ministry of Health and the Government issued order No. 185 of 24.01.2020 to establish the Committee for Emergencies of the Ministry of Health. The decree provided for the transfer of authority to the Committee regarding technical management of the health care system. In February 2020, the Cabinet of Ministers adopted the National Plan of measures to prevent the spread of COVID-19 in Ukraine (further as NPM COVID-19), which provided for the formation of the Operational Committee for Emergencies under Ukraine's Cabinet of Ministers (hereinafter referred to as the Operational Committee) headed by the Prime Minister. The responsibility for coordination and response of the Ministry of Health to COVID-19 was transferred to the Chief State Sanitary Doctor of Ukraine and Deputy Minister of Health (COVID-19 Health System Response Monitor, 2022b).

Within the framework of the system of health care management and response to the situation in April 2020, an inter-branch working group was established to improve inter-branch coordination and to carry out an integrated analysis of the health care system's capacity to respond effectively to the spread of COVID-19. The working group includes representatives of the President's Office, Ministries of Finance, Digital Transformation, Internal Affairs, State Border Guard Service, Government Commissioner for Gender Policy, Security Service, National Security and Defense Council, State Criminal and Executive Service (Nataliia et al., 2021; Widjaja, 2021).

Okhabska, I., Budzyn, V., Rybchych, I., Zyma, I., \& Kalichak, Y. (2022). Management of medical institutions on context of provision medical and preventive care in COVID-19 condition. International Journal of Health Sciences, 6(1), 347-356. https://doi.org/10.53730/ijhs.v6n1.4381 
The NPM COVID-19 was developed as a multi-sectoral and adopted by key stakeholders to counteract the negative effects of the pandemic (ministries, other state bodies, and regional authorities). The NPM describes the regional plans of response to the disease in detail, defining key indicators for defining restrictive measures to control the spread of the virus. The NPM also determines entry points in case of an emergency; it contains operational plans for providing medical and preventive care (medical examination, isolation, transportation to the hospital, etc.) in ports, airports, land transport routes on the border. The NPM also identified the main hospitals in each region for providing treatment and preventive care at COVID-19, defined the scenarios of reprevention of the hospital, calculated and distributed supplies of material and technical means. The NPM is regularly updated to form recommendations on monitoring, detection, sorting, case management, treatment of patients.

On March 20, 2020, the Government approved the necessary pharmaceuticals and medical equipment (including the ZUS) for COVID treatment, which are exempt from VAT and import duty. The Cabinet of Ministers resolution No. 226 of March 20, 2020, for medical products (products) of the opposition COVID-19, simplified the procedures for regulation and licensing medical products.

Management of medical facilities in a pandemic situation in Ukraine also provided for the simplification of the use of unregistered medicines recommended by officials (international) regulators, such as the FDA in the United States, the EU Medical Agency, and MHRA in the United Kingdom, for treatment of Covidien- 19 in the concerned country. During the period of coronary distribution, the doctors were legally authorized to use drugs, which are not specified in the treatment manual of Covidien-19 but are effective in treating the disease. The legislation also provides for accelerated procedures for the authorization and clinical trials of drugs associated with COVID-19.

The Ministry of Health of Ukraine has joined the study "Solidarity" under the guidance of WHO (World Health Organization) to accelerate the study of treatment options COVID-19. That is why at the legislative level the Verkhovna Rada adopted normative acts (COVID-19 Health System Response Monitor, 2022b):

1) to strengthen the capacity of the health care system of Ukraine to combat the outbreak of COVID-19 is aimed at:

- Payments' increase to medical personnel who are at the hospital (including self-isolation) in connection with COVID-19 from $50 \%$ to $100 \%$ of average monthly salary;

- Obligatory testing for men with symptoms COVID-19 or for those who have contacted confirmed cases COVID-19, as well as for medical personnel who treat patients with COVID-19, as well as for employees of the National Police and the National Guard who take part in the implementation of measures related to COVID-19 measures;

- The Cabinet of Ministers to order the Ministry of Health to adopt and make timely changes to instructions and protocols for medical personnel during hospitalization and treatment of patients with COVID-19;

- To develop protocols in case of patients' influx with COVID-19 and overload of health care system;

- Coordinate protocols with WHO's (World Health Organization) recommendations and Centers for Disease Control and Prevention (US Health Service);

- Ensure the availability of IDUs in medical institutions. The law aims to provide increased payments to medical workers who are on permanent treatment or self-isolation through COVID (now such medical workers receive $50 \%$ of monthly salary).

It will also start extensive testing to prevent the spread of COVID.

2) Regarding additional guarantees for medical and other personnel involved in the protection of the population from infectious diseases:

- Medical personnel, for which the infection COVID-19 caused disability, will receive at least 300 living minimum wages (630 $600 \mathrm{UAH}$ );

- Medical workers' families died as a result of infection COVID-19, receive 750 minimum wages (1 576 $500 \mathrm{UAH})$; 
- Medical workers' families who died as a result of COVID-19 infection have the same rights and privileges as families of military servicemen who died during service.

In September 2020, the supreme authorities also amended the Law "About medicinal agents" to introduce electronic retail trade-in medical drugs, temporarily providing a case for the sale of drugs via the Internet during a pandemic. Thus, in Ukraine, in the conditions of the prevalence of the coronavirus, many changes have been made to the legislation for the formation of the management mechanism by medical institutions (Figure 1). This mechanism is aimed at effective coordination, prompt response to the situation, monitoring, analysis of the situation of disease spread.

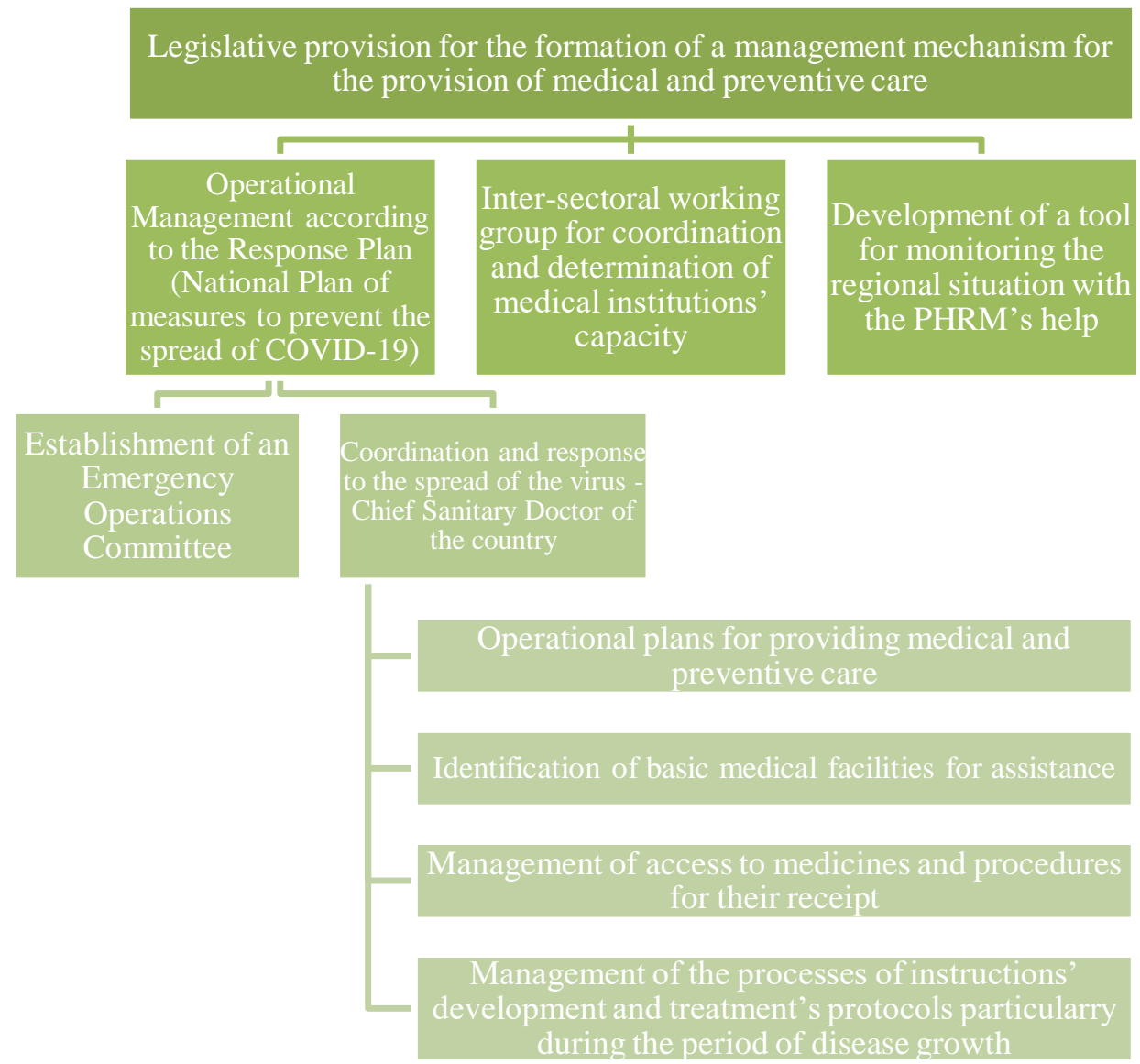

Figure 1. System of medical institutions' management in the conditions of the pandemic in Ukraine Source: developed by the author

Management of the provision of medical and preventive care was centralized but took into account the regional situation of the virus' spread, based on the cooperation of interested parties (ministries and agencies, specially created committees of operational management). At the legislative level, an organizational and financial mechanism for assisting the sick with the use of the existing infrastructure of medical institutions, their technical support, instruments for strengthening the medical institutions' capacity has been formed. In Ukraine within the framework of the NAP, a network of basic medical institutions was formed in each region to provide treatment and preventive care at COVID-19, the scenarios of hospital re-prevention were defined. In total, 71180 beds were allocated in different regions for treatment of patients with viral diseases (Urinov et al., 2021; Widana et al., 2021). By the way on February 06, 2022, 30254 beds were occupied $(42,85 \%$ in the average regions, in particular, $38,41 \%$ of patients with COVID-19).

Okhabska, I., Budzyn, V., Rybchych, I., Zyma, I., \& Kalichak, Y. (2022). Management of medical institutions on context of provision medical and preventive care in COVID-19 condition. International Journal of Health Sciences, 6(1), 347-356. https://doi.org/10.53730/ijhs.v6n1.4381 
Table 1

The bed fund is allocated for COVID-19 in Ukraine (all types), February 06, 2022

\begin{tabular}{lllll}
\hline Region & $\begin{array}{l}\text { Selected under } \\
\text { COVID-19 }\end{array}$ & $\begin{array}{l}\text { Engaged } \\
\text { (in all) }\end{array}$ & $\begin{array}{l}\text { Percentage of } \\
\text { employed } \\
\text { (in all), } \%\end{array}$ & $\begin{array}{l}\text { Engaged (with } \\
\text { COVID-19), } \%\end{array}$ \\
\hline Vinnytskiy region & 2970 & 1475 & 49,66 & 47,27 \\
Volynsky region & 2427 & 1065 & 43,88 & 30,98 \\
Dnipropetrovskiy region & 5236 & 1830 & 34,95 & 29,6 \\
Donetskiy region & 3449 & 1348 & 39,08 & 33,43 \\
Zhytomyrskiy region & 2581 & 1204 & 46,65 & 43,01 \\
Zakarpattskiy region & 1970 & 975 & 49,49 & 46,4 \\
Zaporizhzhkiy region & 2736 & 766 & 28 & 25,04 \\
Ivano-Frankivskiy region & 3382 & 2133 & 63,07 & 58,63 \\
Kyivskiy region & 2303 & 1132 & 49,15 & 41,12 \\
Kirovigradskiy region & 840 & 309 & 36,79 & 32,98 \\
Luganskiy region & 1632 & 587 & 35,97 & 34,74 \\
Lvivskiy region & 5391 & 2309 & 42,83 & 39,05 \\
City Kyiv & 5711 & 1793 & 31,4 & 29,5 \\
Mykolayivkiy region & 2518 & 956 & 37,97 & 34,03 \\
Odeskiy region & 3545 & 1658 & 46,77 & 40,11 \\
Poltavskiy region & 2368 & 641 & 27,07 & 25,51 \\
Rivnenskiy region & 2027 & 1131 & 55,8 & 55,01 \\
Sumskiy region & 2016 & 975 & 48,36 & 46,58 \\
Ternopilskiy region & 1979 & 1090 & 55,08 & 55,08 \\
Kharkivskiy oблactb & 4980 & 2244 & 45,06 & 38,57 \\
Khersonskiy region & 2082 & 564 & 27,09 & 17,96 \\
Khmelnitsky region & 2810 & 1450 & 51,6 & 47,26 \\
Cherkaskiy region & 1940 & 702 & 36,19 & 35,52 \\
Chernivetskiy region & 2152 & 1087 & 50,51 & 42,8 \\
Chernigiskiy region & 2135 & 830 & 38,88 & 30,16 \\
\hline Source: & & &
\end{tabular}

Source: Health care system of Ukraine (2022)

Mitigation of measures (transitional measures): The Directorate on May 25, the WHO Office together with the Ministry of Health and the UCHIC began monitoring the regional response to COVID-19 using the Public Health Response Monitor (PHRM) to improve understanding the way of response in Ukraine and promote coordinated response between the central centers authorities and regional (regional) authorities. On May 27, 2020, the Government:

- Approved the program of economic stimulation to overcome the consequences of the pandemic COVID19. The program takes into account initiatives in such areas: deregulation, Access to finance, access to infrastructure, market access, modernization, and development;

- Supported the initiative of the Ministry of Health and expanded the list of health care facilities intended for treatment COVID-19, from 339 to 449;

- Continued ban on the export of anti-epidemic products until 1 July 2020.

On June 19, the Verkhovna Rada adopted amendments to the Law on Treatment of COVID-19 concerning the term's extension of the activities relating to the growth's threat of diseases on the coronary disease (COVID19). On July 1, the Cabinet of Ministers proposed to strengthen the administrative responsibility of the state institutions and organizations' owners. The Cabinet of Ministers proposed to the Verkhovna Rada (Parliament) draft law on fines for both individuals and legal entities. The government has abolished some restrictions previously applied to Ukraine as a whole: - When carrying out mass events with the number of participants more than 10 - the number of participants can be more than 10 men with a limit of 1 participant per 5 square meters; participants must follow the distance of 1,5 meters; - about the work of public catering services (restaurants, cafes, etc.), shopping and entertainment centers, accommodation services (hotels, hostels), entertainment facilities, fitness centers, etc. The government also introduced changes in the working 
hours of executive bodies, state authorities, administrative service centers, social protection institutions, and the Pension Fund units of Ukraine. Other companies also call for changes in their schedules to avoid the passengers' concentration in public transport. With the introduction, of the epidemiological district strategy in July, the government delegated the regional authorities the right to make decisions on strengthening antiepidemic measures through the regional commission on technogenic and ecological safety and emergencies taking into account epidemiological criteria.

\subsection{Discussions}

In Ukraine, medical institutions' management in the pandemic is based on centralized authority, borrowing European standards of European countries and WHO (World Health Organization) recommendations. The basis of management is the development of strategies for the management of the medical institutions' system, plans for emergency response. At the same time, such national documents don't always provide effective management and are not always approved in all EU countries, but they help to reduce the negative consequences of the disease's spread. For example, during the pandemic, there was no national universal health coverage policy or strategy approved in the Czech Republic and Spain, so there was a weakness in the management of the health care system during the pandemic. At the same time, there are low levels of digitalization in countries. It is one of the main controls for disease monitoring and operational management (e.g., eHealth to support universal health coverage). For comparison, the National eHealth policy or strategy exists have been conducted in Germany and Italy. They provided funding mechanisms, emergency management, and the digitization of the World Health Organization (2021). This was the reason why the number of tele- and video consultations in Germany during the pandemic was growing due to the lifting of restrictions in the field of telemedicine, the virtual hospital started to work, the "CovApp" online resource for health assessment of patients (a new online tool for telemedicine, which provided information support to patients in assessing symptoms and resolving issues, having a deal with COVID-19) started up. At the same time, in all countries, the monitoring instruments of the situation, for medical institutions management are being implemented despite the level of medical institutions' digitalization as an aid management's element. For example, the Government of Germany has approved the "Law about the future of hospitals" for the development of digital infrastructure for the next few years. These measures show how pre-prepared health care management strategies and digitalization strategies improve the health care management quality during a crisis. In Italy, the governance technological component was also strengthened during the pandemic.

\section{Conclusion}

The article identifies the main elements of the health system management mechanism during the pandemic, which includes coordinated work by stakeholders to ensure a coordinated response to the emergency. The mechanism includes the organizational, legal, and financial components of cooperation between agencies and ministries of national, regional level, involvement of international organizations in the process of policy and tactics' development, management crisis' strategies. Strategic documents of the national level are one of the main elements of the management's system, which during the period of the coronavirus expansion allows forming operative regional plans of granting and organization medical assistance to the population (Hick et al., 2020). In the absence of strategic documents, the country's government should ensure the development of a national response plan immediately. It will determine the mechanism for providing assistance and reducing the risks of the negative health crisis' consequences based on an assessment of the medical institutions' capacity (Small Jr et al., 2017). Digital capacity monitoring tools are a significant element of the management's system of medical and preventive care because they provide remote support to the population and reduce the burden on medical personnel and hospital infrastructure.

Acknowledgments

We are grateful to two anonymous reviewers for their valuable comments on the earlier version of this paper.

Okhabska, I., Budzyn, V., Rybchych, I., Zyma, I., \& Kalichak, Y. (2022). Management of medical institutions on context of provision medical and preventive care in COVID-19 condition. International Journal of Health Sciences, 6(1), 347-356. https://doi.org/10.53730/ijhs.v6n1.4381 


\section{References}

Barzylovych, A., Oliinyk, Y., Kostitska, I., Shakhman, N., \& Buryk, Z. (2020). Transformation of the Social and Medical Spheres under the Conditions of COVID-19. Systematic Reviews in Pharmacy, 11(11), 1328-1337.

Beaulieu, M., \& Bentahar, O. (2021). Digitalization of the healthcare supply chain: A roadmap to generate benefits and effectively support healthcare delivery. Technological forecasting and social change,167, 120717. https://doi.org/10.1016/j.techfore.2021.120717

Bokhoree, C., Beeharry, Y., Makoondlall-Chadee, T., Doobah, T., \& Soomary, N. (2014). Assessment of environmental and health risks associated with the management of medical waste in Mauritius. APCBEE procedia, 9, 36-41. https://doi.org/10.1016/j.apcbee.2014.01.007

Correia, T., Dussault, G., \& Pontes, C. (2015). The impact of the financial crisis on human resources for health policies in three southern-Europe countries. Health Policy, 119(12), 1600-1605. https://doi.org/10.1016/j.healthpol.2015.08.009

Economou, C., Kaitelidou, D., Kentikelenis, A., Maresso, A., \& Sissouras, A. (2015). The impact of the crisis on the health system and health in Greece. In Economic crisis, health systems and health in Europe: Country experience [Internet]. European Observatory on Health Systems and Policies.

Fasano, A., Cereda, E., Barichella, M., Cassani, E., Ferri, V., Zecchinelli, A. L., \& Pezzoli, G. (2020). COVID-19 in Parkinson's disease patients living in Lombardy, Italy. Movement Disorders, 35(7), 1089-1093.

Garmann-Johnsen, N. F., Helmersen, M., \& Eikebrokk, T. R. (2020). Employee-driven digitalization in healthcare: codesigning services that deliver. Health Policy and Technology, 9(2), 247-254. https://doi.org/10.1016/j.hlpt.2020.03.001

Gjellebæk, C., Svensson, A., Bjørkquist, C., Fladeby, N., \& Grundén, K. (2020). Management challenges for future digitalization of healthcare services. Futures, 124, 102636. https://doi.org/10.1016/j.futures.2020.102636

Glauner, P., Plugmann, P., \& Lerzynski, G. (2021). Digitalization in Healthcare. Springer International Publishing.

Health Care System of Ukraine (2022). Bed stock is allocated under COVID-19: all types.

Hick, J. L., Hanfling, D., Wynia, M. K., \& Pavia, A. T. (2020). Duty to plan: health care, crisis standards of care, and novel coronavirus SARS-CoV-2. Nam Perspectives, 2020.

Jang, Y. C., Lee, C., Yoon, O. S., \& Kim, H. (2006). Medical waste management in Korea. Journal of environmental management, 80(2), 107-115. https://doi.org/10.1016/j.jenvman.2005.08.018

Kokshagina, O. (2021). Managing shifts to value-based healthcare and value digitalization as a multi-level dynamic capability development process. Technological Forecasting and Social Change, 172, 121072. https://doi.org/10.1016/j.techfore.2021.121072

Lapão, L. V. (2019). The future of healthcare: the impact of digitalization on healthcare services performance. In The internet and health in Brazil (pp. 435-449). Springer, Cham.

Moro Visconti, R., \& Morea, D. (2020). Healthcare digitalization and pay-for-performance incentives in smart hospital project financing. International journal of environmental research and public health, 17(7), 2318.

Nataliia, V., Barzylovych, A., Zabolotna, A., Boiko, M., \& Rybchych, I. (2021). Healthcare facilities management in digitalization context. International Journal of Health Sciences, 5(3), 429-440. https://doi.org/10.53730/ijhs.v5n3.1773

Odone, A., Buttigieg, S., Ricciardi, W., Azzopardi-Muscat, N., \& Staines, A. (2019). Public health digitalization in Europe: EUPHA vision, action and role in digital public health. European journal of public health, 29(Supplement_3), 28-35.

Paital, B., Das, K., \& Parida, S. K. (2020). Inter nation social lockdown versus medical care against COVID-19, a mild environmental insight with special reference to India. Science of the total environment, 728, 138914. https://doi.org/10.1016/j.scitotenv.2020.138914

Roy, B., Nowak, R. J., Roda, R., Khokhar, B., Patwa, H. S., Lloyd, T., \& Rutkove, S. B. (2020). Teleneurology during the COVID-19 pandemic: a step forward in modernizing medical care. Journal of the neurological sciences, 414, 116930. https://doi.org/10.1016/j.jns.2020.116930

Saghazadeh, A., \& Rezaei, N. (2020). Towards treatment planning of COVID-19: Rationale and hypothesis for the use of multiple immunosuppressive agents: Anti-antibodies, immunoglobulins, and corticosteroids. International https://doi.org/10.1016/j.intimp.2020.106560 immunopharmacology, 84,
106560. 
Shamshurina, N. G., Shamshurin, V. I., Laamarti, Y. A., Ryabchikova, L. N., Nikolaev, A. A., \& Peremibeda, P. A. (2021). Public administration strategy of healthcare system for seniors. International Journal of Health Sciences, 5(3), 630-638. https://doi.org/10.53730/ijhs.v5n3.2720

Small Jr, W., Bacon, M. A., Bajaj, A., Chuang, L. T., Fisher, B. J., Harkenrider, M. M., ... \& Gaffney, D. K. (2017). Cervical cancer: a global health crisis. Cancer, 123(13), 2404-2412.

Todurov, B., Bitsadze, A., \& Shorikova, D. (2021). Early postoperative complications in patients with acute myocardial infarction during emergency coronary bypassing. International Journal of Health Sciences, 5(3), 550-564. https://doi.org/10.53730/ijhs.v5n3.2381

Urinov, M., Alikulova, N., Zukhritdinova, D., Usmonov, M., \& Urinov, R. (2021). Clinical, laboratory and instrumental indicators in patients who have undergone COVID-19. International Journal of Health Sciences, 5(3), 403-415. https://doi.org/10.53730/ijhs.v5n3.1719

Wahyuni, S., Chalid, S. M. T., Pelupessy, N. U., Arifuddin, S., Idris, I., \& Usman, A. N. (2022). Comparison of the use of shock index and modified early obstetric warning score in COVID-19 obstetric emergency patients as ICU care parameters. International Journal of Health \& Medical Sciences, 5(1), 80-90.

Wheeler, C., Lloyd-Evans, B., Churchard, A., Fitzgerald, C., Fullarton, K., Mosse, L., ... \& Johnson, S. (2015). Implementation of the Crisis Resolution Team model in adult mental health settings: a systematic review. BMC psychiatry, 15(1), 1-14.

Widana, I.K., Sumetri, N.W., Sutapa, I.K., Suryasa, W. (2021). Anthropometric measures for better cardiovascular and musculoskeletal health. Computer Applications in Engineering Education, 29(3), 550561. https://doi.org/10.1002/cae.22202

Widjaja, G. (2021). Impact of human resource management on health workers during pandemics COVID-19: systematic review. International Journal of Health \& Medical Sciences, 4(1), 61-68.

World Health Organization (2021). National eHealth policy or strategy exists.

Zhao, Y., \& Canales, J. I. (2021). Never the twain shall meet? Knowledge strategies for digitalization in healthcare. Technological Forecasting and Social Change, 170, 120923. https://doi.org/10.1016/j.techfore.2021.120923

Okhabska, I., Budzyn, V., Rybchych, I., Zyma, I., \& Kalichak, Y. (2022). Management of medical institutions on context of provision medical and preventive care in COVID-19 condition. International Journal of Health Sciences, 6(1), 347-356. https://doi.org/10.53730/ijhs.v6n1.4381 


\section{Biography of Authors}

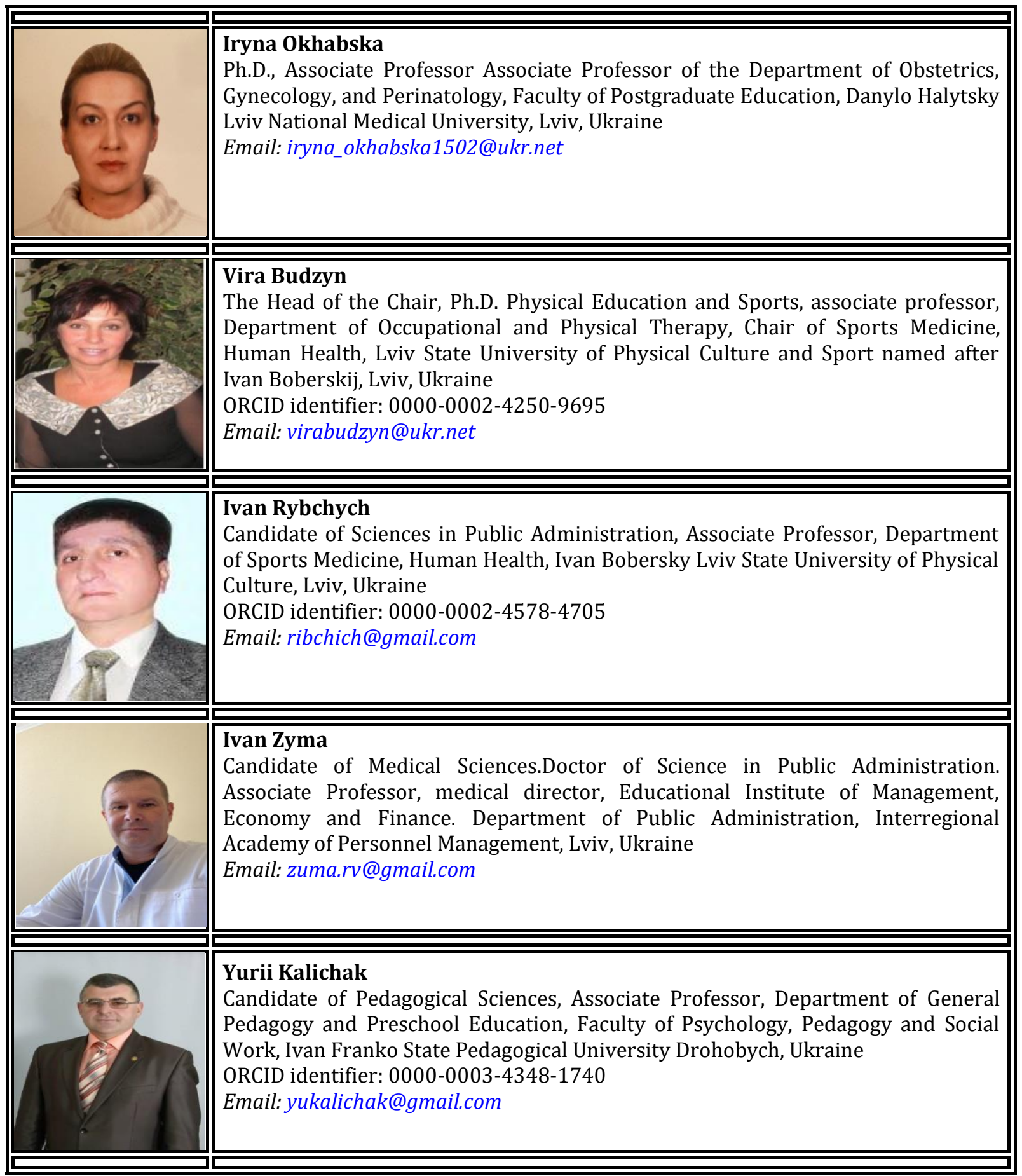

